(2) ソ連中央アジアにおける工業化をめぐって

木 村 英 喜 (横浜国立大学)

はじめに

もと植民地であったロシア周辺諸民族地域の革命後のめざましい発唗は，今甘，第三世界の人々の注

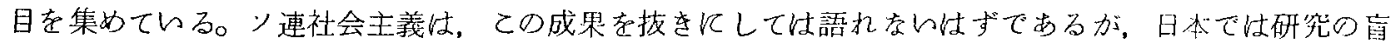
点となっている上5に思加る。とてでは，ソ連中央アジアの人の6割・1.577万を占めるげかりで なく経済的にも要の地位にあるウズベク共和国をとりあげ。最近発表された数字にもとづて簡戦に紹 介したh。

中央アシアは，1867年タシケントのトルケスタン総督府設置を画期として。ロシアに原綿老供給する 植民地となった。1917 年 11 月 1 日にはタシケントにロシア人労㗢者・兵士を中核とするンヴェト政権 が樹立され，国内戦・民族的境界区分を経て。1924 年にウズベク共和国が成立した。それ以後，20 年代

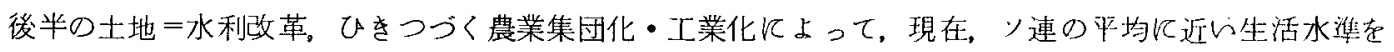
達成している。

ウズベク共和国の工業化の歷史には、ソ連工業の一部としての共通の性格とともに，特殊性すある。 今後の経斎発展においては次の上ら左有利な条件をもっている。

1 スラブ系諸民蔟等とは対照的に，人口増加率が高く労衝力が豊富であること。

2 シベリアと同しく, 天然カス等のエネルギー資源その他の天然資源に富んでいるとと。

3 現在耕地性領域の一割にみをないか，灌溉整備によっで、土地利用の面で可能性をもっている とょ。

4 隣接する中近東地域の発展ととるに，相互の経済協力強化の可能性定もっているとと。

\title{
I. ウズベキスタン工業化の諸時期
}

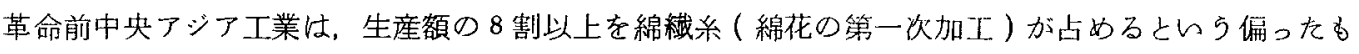
のであった。工業労㗢者は約 2 万人 ( らちロシア人 4800$)$, 鉄道労働者 1 万 6000 人(らちロシア人 1 万 3000 )である。

共和国の工業化は，綿花栽培の発展と緊密に結びついており，大きく4つの段階に分けられる。

第 1 は 1928 年ごろなでの復興期である。この地域での国内戦の長期化と篗溉施設の破壊に上る綿花 栽培復興のおくれにより，綿花精製工業生産は，1927/28 年にはまだ 1913 年の $81.9 \%$ あっったが，食 料品工業等他の部門が発展し，全体としては戦前水淮に復興した。

第 2段階は 1928-40年で, 綿花生産は 55.5 万トン（1928 年）から164.9万トン ( 1941 年) と全面的 集団化運動期間中も增大し，乙れを基礎に，綿花精製工業生産は 3.5 倍以上，搾油も 3 倍弱となった。し かし機械製作・金属加工・䋐維・食料品等の部門の建設に上って工業は多様化し，綿花第一次加工部門 の比重㤌 $86.7 \%$ から $38 \%$ ○下った。失業も31年末になくなる

第 3 段階は大祖国戦争期である。ソ連の西部地域から多くの大機械製作工業・鉄鋼業等の工場が踈開 され, 重工業の比率は 1940-45 年に $13.3 \%$ 多 $54.3 \%$ 一急增した。発電量・採炭量は 3 倍，採油 4 倍 
となった。工業への投資比率は高く，工業フォンドは2倍となった。工業生産全体としてはわずかしか 伸びなっっが，戦後の工業発展の土台がすえられたといえよう。

戦後期は，あらのる部門が高テンボで発展し，生産の部門別比率はソ速に近いすのとなっている。ま た，1960 年代以降は，天然ガス・非鉄金属など全連邦的意義をるつ鉱物資源の採掘・加工の面でも飛躍 的索発展を遂げた。

\section{1. ウズベキスタン工業化の諸特徵}

共和国の住民 1 人あたり国民所得は，1975 年現在ン連の $63.0 \%$ (物的生産従事者1人あたりでは 80.3

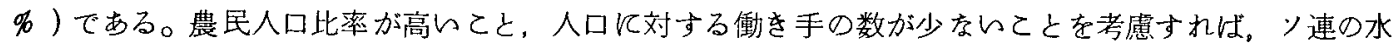
準に接近しているといえるであるら。

投盗においては，第 1 次五力年計画期は工業は $18.7 \%$ \%農業の比重が $54.5 \%$ \%大をいが。第 2 次は工 業は 31.4 ，農業 18.8 ，第 9 次は工業 26.2 , 農業 33.3 と最近をた農業投資の比率が增大しつつある。

工業生産構造では，1913 年軽工業 $83.6 \% 5$ 万 $81.4 \%$ が綿花精製であったが，1975 年は重工業が 47. $0 \%$ となり，綿花精製は軽工業 $34.7 \%$ \% $18.8 \%$ にすぎない。このよに均衡のとれた形に総合的発展を とげたとはいえ，んくつかの特徴がみられる。

\section{1 工業生産の発展と部門別構造における変化}

共和国の工業化は，綿花の第一次加工をてととして，ソ連全体の工業化寄与しつつ，その関連部門 起展させながら行なわれた。つまり共和国の工業は、ソ連経済の有機的構成部分として，分業体制の 一環として形成されたのである。綿花関連部門の優先的発展が，共和国にとっても，ソ連全体にとって も，最大の経済的効果をあげうるからである。庆貨物の遠距離輸送を少なくするため，共和国で消費 されるるのはでさる限りての地域で生産するというるら一つの方もはっをりしている。

\section{1 ) 綿花関連工業の発展}

中央アジアとカザフスタンは 1913 年 66.1 万トンの綿花を生産したが，79年には841.9万トンと13倍 近くなった。79年ソ連全体では 916.1 万トンで合衆国と 1 位を争っている。共和国はをの $62.9 \% 576.3$

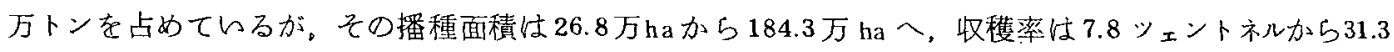

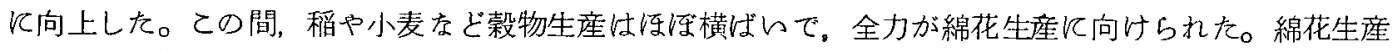
のこのような発展は，その李共和国における綿花第一次加工工業の発展につながる。しかし，ま口・ ケナファ・カラクリ等の生産も伸び，その加工と天然汃ス・鉱産物加工の発展火上って，共和国生産手 段生産中の綿花第一次加工の比率は 1955〜 75 年の短い期間だけで 85.8\%から24.7\%人急減したととに 注目する必要があるら。革命前にはむったくなかった紡績・織物工業も発展し，植民地的経済構造は改 造された。ただ共和国で紡績禾に加工される調達綿花の比率は1975 年現在わずか $3 \%$ \%ずない。 $10 \%$ を共和国で加工するのが適切だとする研究すすり,さらに紡績・織物コンビナートの建設が進めら れている。

\section{2）機械製作工業・化学工業}

綿花栽培怔期間に集中的に人手がかかるため，発展のためには機械化が強く要請された。1931年 5 月にタシケント農業機械工場が操業を始め, 大祖国戦争中はとくに発展し, 綿花収穫機生産る行なわれ るよらになった。単位面積あたり世界最高の綿花収穫高を支えているのは，1940年 1600 トンから79年 645 万トンと生産を伸ばした化学工業である。1966 年でろすで窒素肥料需要の8 割以上, リン肥料の 
7 割以上が地域でみたされている。その他電気機器等の労働集約的な部門・プラスチック製品生産部門 の工場などが農村・小都市に立地され，建設されている。

\section{3 ）消費手段生産部門の発展亡新資源の開発}

食料品工業も午詰工業をど，果物等の生産の增大とともに発展している。地下資源も1940 年に70万 $m^{3}$ でっっ天然ガス生産が、75年 372 億 1100 万 $m^{3}$ ・連の生産高の 13 \%をなら，70 年ウズベキスタ ン燃料の $86.8 \%$ 在去交っている。75年に仕産出量の73.9\%走他地域に供給しており，65.6\%の非鉄 金属とともに全り連的生産物となっている。

\section{2 労働力をめぐる諸問題}

\section{1) 共和国人口動向の特徵}

共和国の人口は 1926 年 466 万， 39 年 644 万， 59 年 811.9 万， 70 年 1196 万， 80 年 1576.5 万と增大 し，とくに59 年以後の 20 年で 2 倍近くになった。79年の自然増加率は千人むたりウクライナ3.6亿対し 27.4 であり，とくに農村の出生率恃高い。共和国の人口構成上の特徽は，農村人口が 80 年に依然とし て $58.8 \%$ あることである。 $40 \sim 80$ 年に都市人口す 160.6 万から 650 万人急增したが, 農村人口す 494. 5 万が 5926.5 万人倍增している。乙のような農村人口増大怯。ソ連内では中央アジア，カザフスタン。 モルダヴィアのみである。播種面積はこの期間に 303.6 万 ha から 391.62 万 ha へ增えただけで，機械化 の進展という条件を考えると，手のかかる綿花栽培の面積が，92.35 万から 184.32 万 ha入倍增したとと によってての学㗢力を吸収したものと思われる。工業労㗢者数は 1975 年には13年の40倍となったが, 今日の主要課題は有資格労働者の養成と原住諸民族婦人の工業への引き入れである。工業の重心はフ ェルガナ州からタシケント,サマルカンド州に移っている。ま大大都市の発展が著しく，1970年には人 口 10 万以上の都市に全人口の $57.3 \%$ が集中している。他地域から中央アジア諸都市への人口流入壮多い が，原住諸民族の他地域への移住は少ない。

\section{2 ）有資格労働者の不足亡養成}

革命前ウズべク人の大部分は文盲で，工業労働者はトルケスタン住民の $0.38 \%$ （1908年），原住諸民 族は重要を仕事から排除されていた。1975 年には 78.8 万の中等高等教育を受けた専門家が存在し，死僄 ソ連の平均水準に達した。しかし工業化のテンボに追んつかず，依然として生産発展のネックになって レる。

\section{3）青年労働力の比重の増大}

をとえば 1970 年の共和国農村では土 15 歳以下の子供が $52.5 \%$ を占め, 全体としても人口の 4 分の 1 程 度の就業人口でしかなかった。しかし言いかえれば，てれは資格の高い青年労働者が近く大量に生産に 参加するととを意味する。実際，1970～77 年に就業人口中 30 葴以下の比率は $35.8 \%$ 加 $41.7 \%$ 一と 大幅に增大している。

\section{4) 婦人の進出とその条件}

婦人の地位け 1920 年代後半の土地二水利改革以降根本的変化を遂げ，家庭から社会への進出が始索る。 しかしたとえばウクライナでは外で働いていない女性は8.7\%にすざないが，ウズべキスタンでは60〜 $70 \%$ である。しかも現在女性の就業率は農村では下り気味である。子供の数が多く家事労㗢が大変なと とが理由として考えられる。サーヴィス業の整備と，2割程度の就学前幼児施設の拡充が必要であるら。 宗教や慣習も理由の一つには違いないが，それだけを強調するととは適当でない。 


\section{結 び}

共和国の工業化にとって，ロシア民族の援助は工業化初期における蓄積源の問題・有資格労働者不足 の問題の解決におんて，とくに重要であった。資金面で共和国がどれだけ找出したか明らかでないが， 高い綿花临付洒格をはじめとする農業への援助を考えあわせると，大幅な持ち込みになっているととは 間違いないと思われる。

なお原住諸民族の働き手の比率は工業全部門で $36.2 \%$ ，非鉄治金で $13.3 \%$ ，機械製作・金属加工で18.

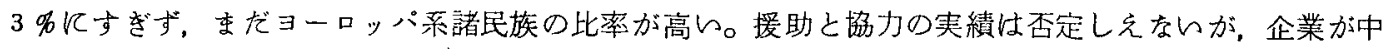
央・地方のロシア人に管理されているといら批判がある。

企業管理は戦後分権化の方向で幾度か再編成されている。ロシア民族と諸民族との関係は, 政治組織

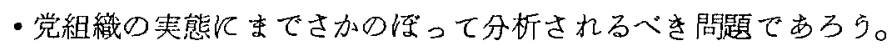

『崩壊した帝国』の著者 $\mathrm{H}$ 。カレールニダンコーズやR。パイプスは，諸民族の経済力・発言権の強化か らソ連邦の崩壊という見通しをひを出しているが，本稿でみてきた共和国工業化は，ン連全体の有機的 部分としての発展であすり，矛盾を過大にみるととはでをないであうう。

ウズベク民族の発展と同時に，たとえば共和国ウズベク人のロシア語修得人口此率が 1970 年の 13.0 \%から79 年 $52.9 \%$ 一飛躍しているといら事実に示されているようなロン丁民族との接近もまた進んで レるのである。

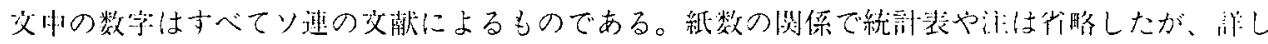

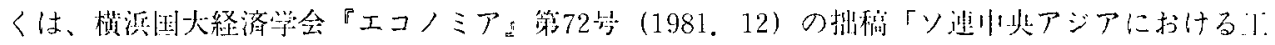
喿化をめぐって」をご参哭いなだければ㨌いである。 